\title{
The influence of different fertilization systems on the quantity and qualitative composition of humus of sod-podzolic soil
}

\author{
Skrylnyk Ye., Kutova A., Hetmanenko V., Gerasymenko Ya. \\ National Scientific Center «Institute for Soil Science and Agrochemical Researches named after O.N. \\ Sokolovsky» \\ 4 Chaikovska Str., Kharkiv, 61024, Ukraine \\ e-mail: orgminlab@gmail.com
}

Goal. To establish regularities of changes of fractional group composition of humus of sod-podzolic soil under the influence of different fertilizer systems in the conditions of Western Polissia. Methods. Field, laboratory analytical, calculation. Results. On the background of liming in the organic fertilizer system, there is a positive trend to increase humic acids in the arable layer of the soil. The organo-mineral fertilizer system creates conditions for the accumulation of resistant to destruction compounds of soil organic matter. The type of humus changes from very fulvate to fulvate. The organo-mineral fertilizer system creates the most favorable conditions for the accumulation of humus in the arable soil layer (the humus content increased by $28.6 \%$ as compared to the control). The degree of mobility of the entire system of humic substances changes in the direction of increasing the organo-mineral fertilizer system and decreasing the mineral and organic fertilizer systems as compared to the control and the background of liming. Conclusions. During long-term agricultural use of sod-podzolic soil at grainplowing crop rotation under the organo-mineral fertilizer system against the background of liming, the humus content in the arable layer increased to $1.53 \%$, the degree of humification of organic matter changed from very high to high. With the introduction of fresh organic matter in the form of manure under organic and organo-mineral fertilizer systems. The content of mobile humic substances increased and the formation of humic acids intensified. The application of only mineral fertilizers increased the content of fulvic acids in soil organic matter.

Key words: application of fertilizers, fractional group composition, humic acids, fulvic acids.

DOI: https://doi.org/10.31073/agrovisnyk202008-02

Soil organic matter, its composition, reserves, features of qualitative characteristics are the main indicators of soil fertility, the change of which largely depends on the intensity of agricultural practices, such as fertilizer application systems [1, 2]. Preservation and increase of fertility of sod-podzolic soil is directly connected with application of organic and mineral fertilizers which essentially influence agrochemical properties. As a rule, their effect on the soil is positive and contributes not only to stabilization but also to improving fertility parameters. The role of organic and mineral fertilizers is fundamentally different. Organic fertilizers have a direct and indirect effect on soil humus: along with the increase in the amount of root and crop residues under the conditions of organic fertilizers, the organic matter of the fertilizers themselves is added. Mineral fertilizers have mainly an indirect effect on soil fertility mostly through the biomass of plant residues, the acid regime of the soil, the activity of biological processes.

Low natural fertility of sod-podzolic soils of Polesia is caused by high filtration of soil, low capacity of absorption of chemical elements, dominance of descending streams of moisture that promotes high migration of watersoluble substances and their leaching outside a humus layer [3].

Researches of L. K. Shevtsova, K. P. Khaidukova, N. N. Kuzmenko [4] demonstrate that under conditions of long-term (60 years) application of organic and mineral fertilizers in 8-field crop rotation on light loam soils, the initial level of humus decreased on control (without fertilizers) and mineral fertilizer system by 30-40\%. The decrease in the humus content was accompanied by a change in the main parameters of its qualitative composition: a decrease in the content of humic acids, increased fulvarization, depletion of soil organic matter by active compounds that are easily mineralized. The low level of chemically and physiologically active organic substances in the soil humus leads to insecurity of the stable, central part of the macromolecule of HA, causing its transformation and biological and chemical destruction, which leads to a decrease in total soil carbon and fertility loss.

In experiments on loamy sod-podzolic soils, organic fertilizers maintained the level of humus content and improved the quality of organic matter compared to control, and the use of mineral fertilizer system enhanced the dehumification [5].

A lot of studies have emphasized the fact of increasing sorghum in the soil under the organo-mineral system of fertilizer application than under the conditions of separate using of mineral and organic fertilizers [6-8].

The specificity of the signs of transformation of humic substances and the degree of their expression in different manifestations of agrogenic influence is a reflection of the nature and depth of changes in the conditions of humification.

The leading role in the manifestation of signs of degradation and regradation transformation belongs to humic 
acids, primarily fractions $\mathrm{HA}-1$ and $\mathrm{HA}-2$, responsible for ensuring the agronomic value of humus and its environmental stability [9]. In different agricultural conditions there is a weakening or activation of the processes of formation of humic structures and their polymerization, which leads to changes in the content, composition, structure and properties of HA. Humus deficiency, acidification and decalcification, which are observed under conditions of agricultural use of soils, without agrochemicals or with unilateral application of mineral fertilizers, after 4 years of cultivation chemical (physico-chemical) degradation of humus is observed. With the increase in the duration of agricultural use of soil without agrochemicals, there is an increase in this feature, as well as a significant decrease in the process of formation of humic acids [10].

The results of researchers confirm the presence of multidirectional changes in the fractional group composition of humus under the conditions of different fertilizer systems [4, 9, 11, 12].

Therefore, the purpose of our research was to establish the patterns of changes in the fractional group composition of the humus of sod-podzolic soil under the influence of different fertilizer systems in the conditions of Western Polesia.

Research Methodology. The research was conducted in 2019 on the basis of the Volyn State Agricultural Research Station of the Institute of Agriculture of Western Polesia (Volyn region, Lutsk district, Rokyni village), was laid in 1966. Experiment "Influence of the main types of fertilizers and their combinations on crop rotation productivity and soil properties", agricultural crop is winter wheat, predecessor is potatoes.

Initial agrochemical characteristics of $0-20 \mathrm{~cm}$ layer of sod-podzolic soil (stationary experiment, 3rd field, 1966): pHKCL - 5.1; amount of exchange bases S $-2.6 \mathrm{mg}-\mathrm{eq} . / 100 \mathrm{~g}$ of soil; humus content according to Tyurin (DSTU 4289:2004) - 1.39\%; mobile phosphorus according to Kirsanov (DSTU 4405:2005) - 3.9 and mobile potassium according to Maslova (DSTU 7907:2015) - $5.2 \mathrm{mg}$ per $100 \mathrm{~g}$ of soil.

Research scheme: Without fertilizers (control); Background $\mathrm{CaCO}_{3}$; mineral fertilizer system $-\mathrm{N}_{60} \mathrm{P}_{40} \mathrm{~K}_{80}$ on the background of $\mathrm{CaCO}_{3}$; organic system is aftereffect of manure 60 t/ha introduced in 2018 on the background of $\mathrm{CaCO}_{3}$; organo-mineral fertilizer system - aftereffect of manure $60 \mathrm{t} / \mathrm{ha}$, applied in $2018+\mathrm{N}_{60} \mathrm{P}_{40} \mathrm{~K}_{80}$ on the background of $\mathrm{CaCO}_{3}$.

Liming was carried out once per rotation at the rate of $5 \mathrm{t} / \mathrm{ha}$. The total area of sown areas is 4.6 hectares, the repetition is fourfold. The area of the elementary plot is $90 \mathrm{~m}^{2}$, the accounting area is $50 \mathrm{~m}^{2}$.

Among the mineral fertilizers, ammonium nitrate (33.4\%) is used during pre-sowing application and fertilization; amophos $(\mathrm{P}-51 \%, \mathrm{~N}-10 \%)$ and potassium chloride $(58-60 \%)$ - in the main application in the fall. Cattle manure is applied twice per rotation under potatoes and corn. Type of crop rotation is field (grain-row).

Soil samples were taken from a depth of $0-20 \mathrm{~cm}$ of soil layer in triplicate. To form a mixed soil sample, 5 individual samples were taken by the "envelope" method. Sampling of soil samples and their preparation for analysis was carried out in accordance with the requirements of DSTU 4287: 2007.

The analysis of soil samples was performed according to the current regulatory and methodological documents in the laboratory of organic fertilizers and humus of National Scientific Center «Institute for Soil Science and Agrochemistry Research named after O.N. Sokolovsky» (certificate of compliance of the measurement system with the requirements of DSTU ISO 10012: 2005, № 01-0104/ 2017 and № 01-0105 / 2017): pre-treatment of samples according to DSTU ISO 11464; determination of dry matter and moisture by gravimetric method according to DSTU ISO 11465; determination of total carbon content by the Turin method according to DSTU 4289: 2004; determination of group and fractional composition of humus by the method of Tyurin in the modification of Ponomareva and Plotnikova according to DSTU 7828: 2015; the parameters of the humus system were evaluated by a system of indicators [13]. The degree of humification of soil organic matter was determined by the equation $\mathrm{CHA} /$ Ctotal $\times 100 \%$. The humus content was determined by a conversion factor of 2.09 for sodpodzolic soils.

Elaboration and generalization of research results was performed using the methods of Statistica 6.

Results and Discussion of the Research. For 53 years of agricultural using of sod-podzolic soil under grainrow crop rotation under different agrochemical loading, signs of humus transformation with different degrees of severity at different levels of its organization were revealed. It was found that under the conditions of application of the organo-mineral fertilizer system the content of humic acids of fraction I increased 3 times, in the mineral system - almost 2 times compared to the control and unfertilized background (Table 1).

Systematic application of fertilizers activates the development of the root system of crops and as a result the content of the most mobile group of organic matter, which is extracted $0.1 \mathrm{n} \mathrm{H}_{2} \mathrm{SO}_{4}$ during decalcification, is halved in the arable layer of the soil, compared to the options without fertilizers. This indicates that mobile organic matter is rapidly mineralized and is a source of nutrients for crops.

Liming reduced the HA-2 content of calcium bound in the soil by half compared to the unfertilized control. Against the background of liming only in the organic system of fertilizers there is a positive trend to increase humic acids in the arable soil layer. The application of mineral fertilizers led to a decrease in the content of HA-2 in half compared with the background of liming and 4.5 times compared to the unfertilized control. Against the background of an increase in humic acids, the content of FA-2 in the organo-mineral fertilizer system decreases accordingly. The use of only mineral fertilizers doubled the content of FA-2 compared to the background of liming. 
1. Influence of different fertilizer systems on the group and fractional composition of humus of sodpodzolic soil

\begin{tabular}{|l|c|c|c|c|c|c|c|c|c|c|c|}
\hline \multirow{2}{*}{ Variant } & \multirow{2}{*}{$\begin{array}{l}\text { Ctota } \\
\text { I, \% }\end{array}$} & 1 & 2 & 3 & $\Sigma$ & $1 \mathrm{a}$ & 1 & 2 & 3 & $\Sigma$ & Chumines \\
\cline { 3 - 13 } $\begin{array}{l}\text { Without } \\
\text { fertilizers } \\
\text { (control) }\end{array}$ & 0,57 & $\frac{0,04}{7,0}$ & $\frac{0,09}{15,8}$ & $\frac{0,14}{24,6}$ & $\frac{0,27}{47,4}$ & $\frac{0,04}{7,0}$ & $\frac{0,14}{24,6}$ & $\frac{0,01}{1,7}$ & $\frac{0,10}{17,5}$ & $\frac{0,29}{50,8}$ & $\frac{0,01}{1,8}$ \\
\hline Background & 0,62 & $\frac{0,05}{8,1}$ & $\frac{0,04}{6,5}$ & $\frac{0,09}{14,5}$ & $\frac{0,18}{29,0}$ & $\frac{0,04}{6,5}$ & $\frac{0,16}{25,8}$ & $\frac{0,04}{6,5}$ & $\frac{0,20}{32,3}$ & $\frac{0,44}{71,1}$ & $\frac{0,004}{0,6}$ \\
\hline $\begin{array}{l}\text { Background + } \\
\text { mineral } \\
\text { fertilizer } \\
\text { system }\end{array}$ & 0,64 & $\frac{0,07}{10,9}$ & $\frac{0,02}{3,1}$ & $\frac{0,14}{21,9}$ & $\frac{0,23}{35,9}$ & $\frac{0,02}{3,1}$ & $\frac{0,14}{21,9}$ & $\frac{0,08}{12,5}$ & $\frac{0,16}{25,0}$ & $\frac{0,40}{62,5}$ & $\frac{0,01}{1,6}$ \\
\hline $\begin{array}{l}\text { Background + } \\
\text { organic } \\
\text { fertilizer } \\
\text { system }\end{array}$ & 0,65 & $\frac{0,05}{7,7}$ & $\frac{0,07}{10,7}$ & $\frac{0,12}{18,5}$ & $\frac{0,24}{36,9}$ & $\frac{0,02}{3,1}$ & $\frac{0,15}{23,1}$ & $\frac{0,04}{6,2}$ & $\frac{0,19}{29,2}$ & $\frac{0,40}{61,5}$ & $\frac{0,01}{1,5}$ \\
\hline $\begin{array}{l}\text { Background }+ \\
\text { organo- } \\
\text { mineral } \\
\text { fertilizer } \\
\text { system }\end{array}$ & 0,73 & $\frac{0,15}{20,5}$ & $\frac{0,05}{6,8}$ & $\frac{0,06}{8,2}$ & $\frac{0,26}{35,6}$ & $\frac{0,02}{2,7}$ & $\frac{0,17}{23,3}$ & $\frac{0,02}{2,7}$ & $\frac{0,24}{32,8}$ & $\frac{0,45}{61,6}$ & $\frac{0,02}{2,7}$ \\
\hline \multicolumn{1}{|c|}{ HIP $_{05}$} & 0,04 & $\frac{0,02}{3,7}$ & $\frac{0,03}{5,8}$ & $\frac{0,02}{6,0}$ & - & $\frac{0,02}{3,6}$ & $\frac{0,01}{1,5}$ & $\frac{0,03}{4,3}$ & $\frac{0,05}{7,2}$ & - & $\frac{0,01}{0,3}$ \\
\hline
\end{tabular}

Notes: 1. Above the line - $\%$ to the ground, under the line - $C$ fraction as a percentage of Ctotal. 2. 1 - the first fraction, 2 - the second fraction, 3 - the third fraction.

There was a significant increase in the content of fulvic acids associated with the mineral part of the soil (FA3) for all fertilizer systems against the background of liming.

Humines are the most stable compounds of soil organic matter, which over time are converted into more carbon-rich compounds. It is investigated that only with the organo-mineral fertilizer system conditions are created for the accumulation of soil-resistant compounds of soil organic matter.

Liming of sod-podzolic soil leads to a significant decrease in the ratio of CHA / CFA from 0.93 (in control) to 0.41 , changing the type of humus from humate-fulvate to very fulvate, which is a sign of a negative direction of the humification process (Table 2).

2. Influence of long-term fertilizer on the humus state of sod-podzolic soil.

\begin{tabular}{|c|c|c|c|c|c|}
\hline Indicator & $\begin{array}{l}\text { Without } \\
\text { fertilizers } \\
\text { (control) }\end{array}$ & Background & $\begin{array}{c}\text { Background + } \\
\text { mineral } \\
\text { fertilizer } \\
\text { system }\end{array}$ & $\begin{array}{c}\text { Background + } \\
\text { organic fertilizer } \\
\text { system }\end{array}$ & $\begin{array}{l}\text { Background + } \\
\text { organo-mineral } \\
\text { fertilizer system }\end{array}$ \\
\hline $\begin{array}{l}\text { Humus content, } \\
\%\end{array}$ & 1,19 & 1,30 & 1,34 & 1,36 & 1,53 \\
\hline Ctotal, \% & 0,57 & 0,62 & 0,64 & 0,65 & 0,73 \\
\hline $\begin{array}{l}\mathrm{CHA}, \\
\% \text { до Ctotal }\end{array}$ & 47,4 & 29,0 & 35,9 & 36,9 & 35,6 \\
\hline $\begin{array}{l}\text { Degree of } \\
\text { humification }\end{array}$ & very high & medium & \multicolumn{3}{|c|}{ high } \\
\hline $\begin{array}{l}\text { CFA, } \\
\% \text { to Ctotal }\end{array}$ & 50,8 & 71,1 & 62,5 & 61,5 & 61,6 \\
\hline $\mathrm{CHA} / \mathrm{CFA}$ & 0,93 & 0,41 & 0,57 & 0,60 & 0,57 \\
\hline Type of humus & humate-fulvate & very fulvate & \multicolumn{3}{|c|}{ fulvate } \\
\hline $\begin{array}{l}\text { HA-1, } \\
\% \text { to the amount } \\
\text { HA }\end{array}$ & 14,8 & 27,8 & 30,4 & 20,8 & 57,6 \\
\hline $\begin{array}{l}\text { HA-2, } \\
\% \text { to the amount } \\
\text { HA }\end{array}$ & 33,3 & 22,2 & 8,7 & 29,2 & 19,2 \\
\hline $\begin{array}{l}\text { HA-3, } \\
\% \text { to the amount } \\
\text { HA }\end{array}$ & 51,8 & 50,0 & 60,8 & 50,0 & 23,1 \\
\hline
\end{tabular}




\begin{tabular}{|l|l|l|l|l|l|}
\hline $\begin{array}{l}\text { The degree of } \\
\text { mobility of the } \\
\text { system of HS }\end{array}$ & 0,64 & 0,76 & 0,56 & 0,52 & 0,92 \\
\hline
\end{tabular}

Note. HA-1 fraction, free and bound to mobile oxides, HA-2 fraction bound to calcium, HA-3 fraction bound to clay fraction and stable oxides.

Using of mineral and organic fertilizers in different doses against the background of liming slightly improves the ratio of the amount of CHA/CFA by changing the type of humus in the arable layer of the soil from very fulvate to fulvate.

Sod-podzolic soil is characterized by a very low humus content $(\leq 2)$. Liming increased the organic carbon content and, accordingly, the humus content in the arable layer by $9.2 \%$ compared to the control. Under the conditions of mineral and organic fertilizers application against the background of liming, the humus content increased by 12.6 and $14.3 \%$, respectively, compared to the control. The organo-mineral fertilizer system on the background of liming creates the most favorable conditions for the accumulation of humus in the arable soil layer, compared with the control, this figure increased by $28.6 \%$.

Differences in the humus state of sod-podzolic soil in the layer of $0-20 \mathrm{~cm}$ at different agrochemical loads were diagnosed by a set of characteristics. The degree of humification of organic matter under the influence of liming changed from very high to medium, the use of fertilizers changed the degree of humification to high. Against the background of a high degree of humification of organic matter, there is a low content of "free" humic acids in addition to the organo-mineral fertilizer system where the content of "free" humic acids corresponds to the average. During the long-term agricultural using of sod-podzolic soil on fertilized variants, the content of "free" humic acids in the arable layer increased 2-3 times compared to the control. The content of humic acids bound to calcium under the influence of fertilizer has changed from low (control) to very low, except for the organic system. The content of strongly bound humic acids in the organic matter of sod-podzolic soil according to the experimental variants remained high $(\geq 20)$. The degree of mobility of the whole system of humic substances (HS) changed in the direction of increase in the organo-mineral fertilizer system and decrease in the mineral and organic fertilizer systems compared to the control and background of liming.

\section{Conclusions}

During long-term agricultural use of sod-podzolic soil under grain-row crop rotation under the organo-mineral fertilizer system against the background of liming, the humus content in the arable layer increased to $1.53 \%$, the degree of humification of organic matter changed from very high to high. Application of fresh organic matter in the form of manure in organic and organo-mineral fertilizer systems increases the content of mobile humic substances and promotes the activation of humic acid formation, application of only mineral fertilizers increases the content of fulvic acids in soil organic matter.

\section{References}

1. Lapa, V. V. (2014). Plodorodie pochv $i$ ispolzovanie udobrenij $v$ Respublike Belarus [Soil fertility and the use of fertilizers in the Republic of Belarus]. Fertility, 3, 19-20. [In Russian].

2. Sharkov, I. N. (2011). Konczepcziya vosproizvodstva gumusa $v$ pochvakh [The concept of humus reproduction in soils]. Agrochemistry, 12, 21-27. [In Russian].

3. Kochik, G. M. (2015). Gumusnij stan dernovo-pidzolistogo gruntu za riznikh sistem osnovnogo obrobitku i udobrennya [Humus condition of sod-podzolic soil under different systems of basic tillage and fertilizer] Zbirnik naukovikh pracz NNCz "Institut zemlerobstva NAAN [Collection of scientific works of NSC "Institute of Agriculture NAAS"]. (pp. 47-57). [In Ukrainian].

4. Shevczova, L. K., Khajdukov, K. P., \& Kuzmenko, N. N. (2012). Transformacziya organicheskogo veshhestva legkosuglinistoj dernovo-podzolistoj pri dlitelnom primenenii udobrenij v Inyanom sevooborote [Transformation of organic matter of light loamy soddy-podzolic soil with prolonged use of fertilizers in flax crop rotation]. Agrochemistry, 10, 3-12. [In Russian].

5. Drichko, V. F., Bakina, L. G., \& Orlova, N. E. (2013). Ustojchivaya i labilnaya chasti gumusa dernovopodzolistoj pochvy [Stable and labile part of humus of sod-podzolic soil]. Soil science, 1, 41-47. [In Russian].

6. Skrilnik, le. V., Kutova, A. M., \& Getmanenko, V. A. (2019). Vpliv sistem udobrennya na organichnu rechovinu ta agrokhimichni pokazniki chornozemu tipovogo [Influence of fertilizer systems on organic matter and agrochemical parameters of typical chernozem]. Agrochemistry and soil science, 88, 74-78. [In Ukrainian].

7. Volodina, T. I., Romanov, G. A., \& Levchenkova, A. N. (2014). Vliyanie razlichnykh sistem udobreniya na fiziko-khimicheskie i agrofizicheskie pokazateli dernovo-podzolistoj pochvy $v$ usloviyakh severo-zapada Rossii [Influence of various fertilization systems on the physicochemical and agrophysical indicators of sod-podzolic soil in the north-west of Russia]. Agrochemistry, 3, 12-21. [In Russian].

8. Kuzmenko, N. N. (2014). Effektivnost dlitelnogo primeneniya raznykh sistem udobreniya $v$ Inyanom sevooborote i ikh vliyanie na izmenenie zapasov gumusa dernovo-podzolistoj pochvy [The effectiveness of long-term use of different fertilization systems in flax crop rotation and their effect on change humus reserves of sod-podzolic soil]. Agrochemistry, 4, 35-39. [In Russian]. 
9. Ovchinnikova, M. F. (2012). Priznaki i mekhanizm agrogennoj transformaczii gumusovykh veshhestv dernovo-podzolistoj pochvy [Signs and mechanism of agrogenic transformation of humic substances in sod-podzolic soil]. Agrochemistry, 1, 3-13. [In Russian].

10. Kaiser, K., \& Kalbitz, K. (2012). Cycling downwards-dissolved organic matter in soils. Soil Biol. Biochem., 52, 29-32.

11. Bogatyreva, E. N., Seraya, T. M., \& Chernysh, A. F. (2013). Vliyanie sevooborotov i sistem udobreniya na soderzhanie i kachestvennyj sostav podvizhnykh gumusovykh veshhestv $v$ dernovo-podzolistykh erodirovannykh pochvakh [The influence of crop rotations and fertilization systems on the content and qualitative composition of mobile humic substances in sod-podzolic eroded soils]. Agrochemistry, 7, 1624. [In Russian].

12. Zavyalova, N. E., Kosolapova, A. I., \& Yamaltdinova, V. R. (2005). Vliyanie dlitel'nogo primeneniya organicheskikh udobrenij na transformacziyu organicheskogo veshhestva dernovo-podzolistoj pochvy. [The effect of long-term use of organic fertilizers on the transformation of organic matter in sod-podzolic soil]. Agrochemistry, 6, 5-10. [In Russian].

13. Orlov, D. S., Biryukova, O. N., \& Rozanova, M. S. (2004). Dopolnitelnye pokazateli gumusnogo sostoyaniya pochv i ikh geneticheskikh gorizontov. [Additional indicators of the humus state of soils and their genetic horizons]. Soil science, 8, 918-926. [In Russian]. 